\title{
Article \\ Community Engagement and Outreach Programs for Lead Prevention in Mississippi
}

\author{
Amal K. Mitra ${ }^{1, *(D)}$ and Charkarra Anderson-Lewis ${ }^{2}$ \\ 1 School of Public Health, College of Health Sciences, Jackson State University, Jackson, MS 39213, USA \\ 2 School of Health Professions, The University of Southern Mississippi, Hattiesburg, MS 39406, USA; \\ charkarra.andersonlewis@usm.edu \\ * Correspondence: amal.k.mitra@jsums.edu; Tel.: +1-601-979-8788
}

Citation: Mitra, A.K.;

Anderson-Lewis, C. Community

Engagement and Outreach Programs for Lead Prevention in Mississippi.

Int. J. Environ. Res. Public Health 2021,

18, 202. https://doi.org/10.3390/

ijerph18010202

Received: 17 December 2020

Accepted: 24 December 2020

Published: 29 December 2020

Publisher's Note: MDPI stays neutral with regard to jurisdictional clai$\mathrm{ms}$ in published maps and institutional affiliations.

Copyright: (C) 2020 by the authors. Licensee MDPI, Basel, Switzerland. This article is an open access article distributed under the terms and conditions of the Creative Commons Attribution (CC BY) license (https:// creativecommons.org/licenses/by/ $4.0 /)$.

\begin{abstract}
The objective of the project was to encourage health promotion through education, outreach, and community-based training. The people attending health fairs $(n=467)$, community events ( $n=469)$, and Kindergarten classes $(n=241)$ were the study participants. Hands-on training was offered at homebuilding retail stores $(n=25)$. U.S. Department of Housing and Urban Development (HUD)'s online visual training was given to realtors $(n=220)$, and inspectors, contractors, and Do-It-Yourself (DIY) workers $(n=75)$. Training workshops were attended by home-buyers and rental home owners at the Neighborhood Association Meetings $(n=91)$. The impact of training was evaluated by pre- and posttests. Nearly, $90 \%$ of the participants $(n=25)$ reported the hands-on training was useful. At posttest after the HUD online training, 59.4\%, 67.9\%, 65.1\% of the participants $(n=220)$ identified soil, car batteries, and paint as sources of lead in the environment, respectively. Nearly $70 \%$ identified lead as a poison in the environment while $77.5 \%$ and $47.2 \%$ demonstrated two behaviors which help prevent lead poisoning. A total of $62.3 \%, 48.1 \%$, and $58.5 \%$, at posttest identified three complications or illnesses-behavioral, physical, and psychological, respectively. The home owners are required to get permission from the City for housing repair. In coordination with the federally funded housing repair or lead abatement programs, the trained inspectors are authorized to certify the renovation or repair works. These outreach activities were successful in improving the knowledge of the community people on lead poisoning prevention.
\end{abstract}

Keywords: lead poisoning; children; prevention; outreach; health education; sources; complications; Mississippi

\section{Introduction}

Globally, $23 \%$ of all deaths and $26 \%$ of deaths among children under age 5 are due to preventable environmental factors [1]. The Environmental Protection Agency recognizes lead poisoning as one of the most preventable health tragedies for children in the United States [2]. Unfortunately, some populations and geographic areas in the U.S. remain at disproportionately high risk for lead exposure [3]. According to the U.S. Department of Urban and Housing Development, there are approximately 3.8 million houses or buildings that have children living in them who are potentially being exposed to lead [4]. Children of some racial and ethnic groups, such as non-Hispanic African-Americans, are at higher risk for exposure to lead. Nearly half a million U.S. children ages 1 to 5 have blood lead levels at or above $5 \mu \mathrm{g} / \mathrm{dL}$, which is currently the reference level at which the Centers for Disease Control and Prevention (CDC) recommends public health actions be taken [5].

Lead toxicity affects almost every organ system of the human body [6]. Long-term exposure to lead can seriously harm a child's health and cause well-documented adverse effects including neurological damage [7], retarded growth and development [8], learning and behavioral abnormalities [9,10], hearing and speech problems [10,11], deficits in cognitive function [12], sleep deficits [13], attention deficiencies, and underperformance in school [13]. 
The Healthy People 2020 [14] and the proposed Healthy People 2030 objectives [15] established the nation's strategy for improving the health and well-being of all citizens, and emphasized to reduce blood lead level in children aged 1-5 years. According to CDC, there is an urgent need to develop health education and outreach activities that are culturally appropriate and sensitive to the target population in reducing disparities in lead poisoning [3].

To provide a comprehensive effort to educating community people on childhood exposure to lead and lead prevention, we developed a community-based participatory research (CBPR) program called Community Lead Awareness Partnership (CLAP) for Healthy Kids in Mississippi. The aims of the program were three-fold: (1) Identify the most affected communities and the risk group of people having high blood level of lead in Mississippi; (2) Evaluate effectiveness of a comprehensive lead education and training program in awareness building and practices on lead prevention among the most affected populations in Mississippi; and (3) Encourage sustainable infrastructure development programs for the prevention of childhood lead poisoning.

\section{Materials and Methods}

\subsection{Community Partnership}

In this CBPR program, we developed partnership with a number of community organizations and stakeholders in Mississippi (Figure 1). The partners included Mississippi State Department of Health Lead Poisoning Prevention and Healthy Home Program (LPPHHP), the National Paint and Coatings Association (NPCA), a local Community Housing Development Organization (CHDO), Hattiesburg City Government, the Head Start Program, community and faith-based organizations, day-care centers, public schools, home buyers, local contractors, and realtors. The program objectives and activities were developed based on discussions with the partners. A Community Advisory Board (CAB) comprising of representatives from each partner organization and the investigators met quarterly to discuss on strategies and monitor progresses.
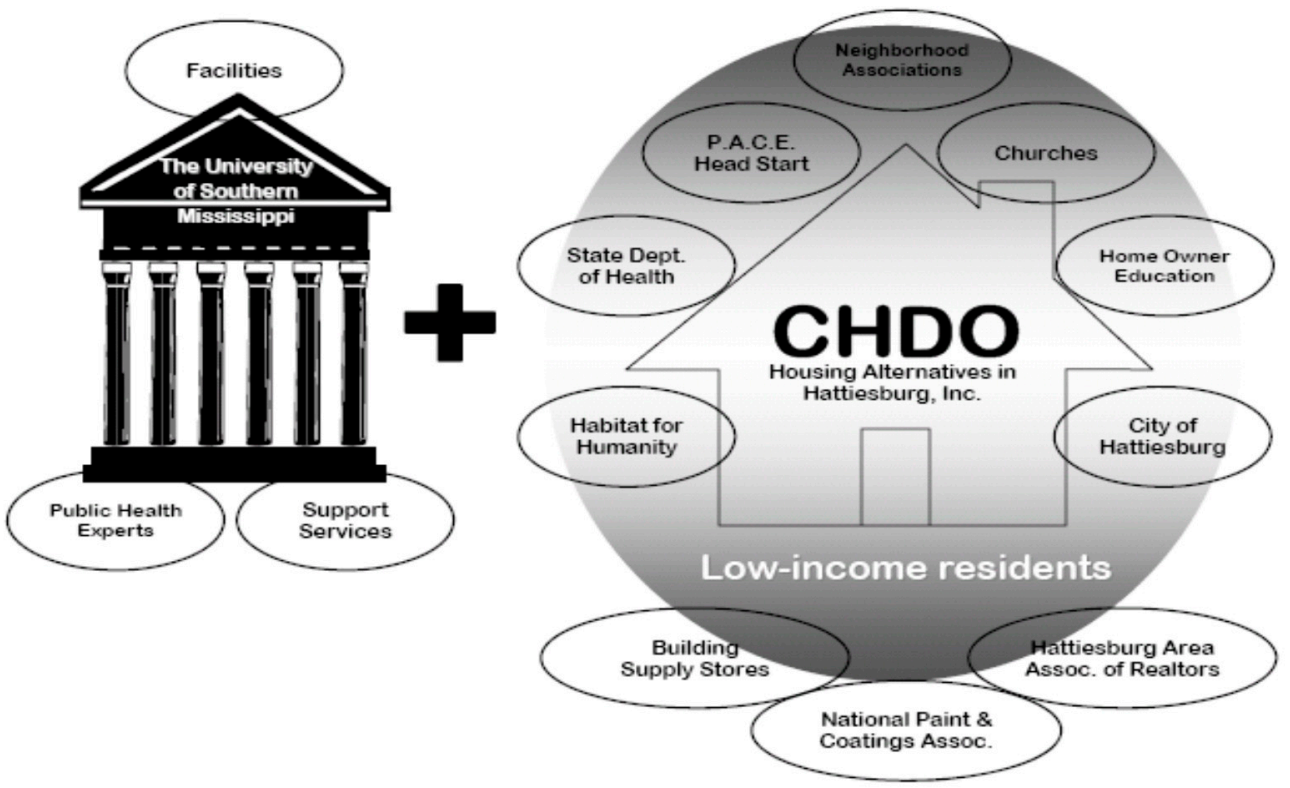

Figure 1. A list of community partners involved in the program.

\subsection{Identification of High-Risk Populations}

We used the CDC criteria for the identification of "high risk" areas, which states that if $12 \%$ or more of children tested for blood lead levels (BLL) are found with raised levels of lead, the area will be designated as a "high-risk" area [16]. In order to focus our efforts in the most vulnerable populations with lead poisoning, we analyzed 42,372 records of 
children aged less than 6 years in Mississippi. The data were obtained from the Mississippi State Department of Health LPPHHP. Overall, 2446 children in Mississippi (5.8\%) had high blood lead levels (BLL) $\geq 5 \mu \mathrm{g} / \mathrm{dL}$. However, nine counties in the state reported $12 \%$ or more of the children tested had high BLL. These counties, in order of the highest to the lowest levels of BLL included Forrest, Oktibbeha, Covington, Coahoma, Greene, Grenada, Pike, Jones, and Yazoo (Figure 2). The City of Hattiesburg, being the largest city in the Forrest County of Mississippi, and having the highest proportion of childhood BLL, was selected as the study site. The project activities targeted population living in the areas of low-income residences of Forrest County.

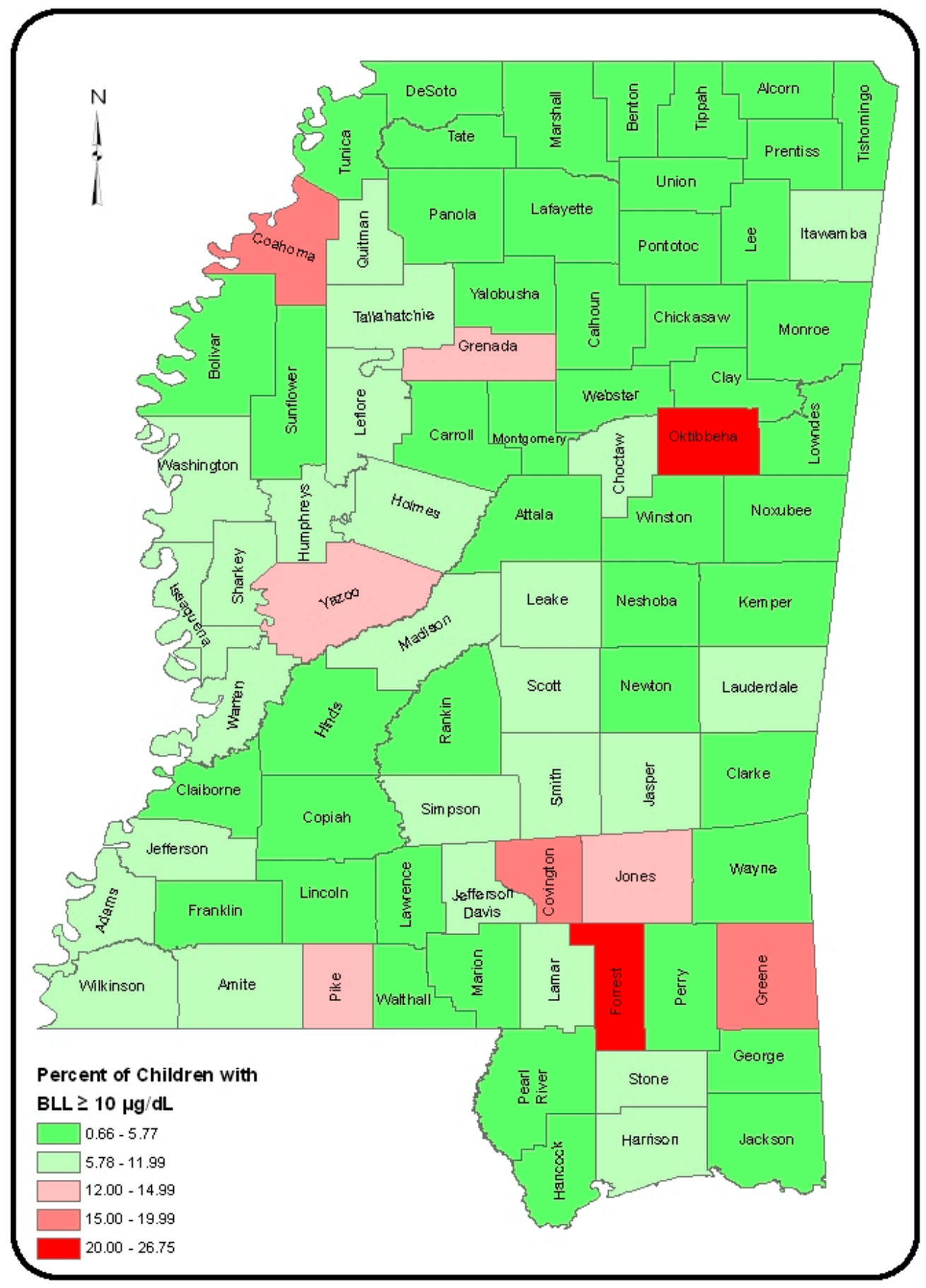

Figure 2. Percent of children with blood levels of lead in 82 countries of Mississippi. 
Results of the secondary data analysis of the Mississippi State Department of Health (MSDH) data and the impact of the lead education and training programs are presented in Figure 2.

\subsection{Project Goals, Activities, and Measurable Outcomes}

Goal 1. Encourage health promotion by conducting community-based outreach concerning childhood lead poisoning prevention.

Activity 1. Provide health education materials, educational training, and presentations to community-based organizations, child-care centers, and faith-based communities. Specific project output: Participate in 10 health fairs; disseminate 600 educational materials; and make presentations to 10 local community-based partner organizations. Measurable outcomes: At post-test, $90 \%$ of these participants are able to (a) Identify three primary sources of lead in the environment (paint, dust, and soil); (b) Identify lead as a poison found in the environment and demonstrate a minimum of two behaviors which will help prevent lead poisoning; and (c) Identify a minimum of three complications (physical, mental, or psychological) of lead poisoning.

Activity 2. Partner with local home-builder retail stores (such as Home Depot and Lowe's) to host hands-on training on lead poisoning prevention. Specific project output: Conduct two training sessions on lead poisoning prevention and lead-safe home repairs (one in each facility). Measurable outcomes: $50 \%$ reported the hands-on training was useful for prevention from lead contamination.

Activity 3. Encourage all realtors to take the U.S. Department of Housing and Urban Development (HUD)'s free online Lead-Based Paint Visual Assessment Training [17]. Specific project output: 75 Hattiesburg realtors will complete the online training. Measurable outcomes: $90 \%$ of participants report they will use information obtained in the training.

Goal 2. Encourage health promotion by conducting community-based training activities on childhood lead poisoning prevention.

Activity 1. Conduct home-buyer education classes that include curriculum on lead poisoning prevention. Specific project output: Conduct 12 home-buyer education classes that include curriculum on lead poisoning prevention; and yearly home maintenance education course. Measurable outcomes: At post-test, $75 \%$ of these participants are able to (a) Identify three primary sources of lead in the environment (paint, dust, and soil); (b) Identify lead as a poison found in the environment and demonstrate a minimum of two behaviors which will help prevent lead poisoning; and (c) Identify a minimum of three complications (physical, mental, or psychological) of lead poisoning.

Activity 2. Provide intensive training on lead-safe work practices to inspectors, contractors, and Do-It-Yourself (DIY) workers. Specific project output: Train 3 inspectors, 25 contractors, and 25 DIY workers on the 8-h U.S. Department of Housing and Urban Development (HUD) curriculum on lead. Measurable outcomes: $75 \%$ of participants will report at follow-up survey that they use information obtained during the training.

Activity 3. Provide training in lead-safe work practices and compliance with Toxic Substances Control Act (TSCA) Section 1018 to rental property owners. Specific project output: Hold one seminar for rental property owners on lead-safe work practices. Measurable outcomes: At follow-up, $60 \%$ of participants will report they use the information presented at the seminar.

\subsection{Data Collection Instruments}

A summary of the training activities, data collection procedures, training materials, and the assessment methods are presented in Table 1. The assessment instruments were: (1) Exit survey for participants for hands-on training at home builder retail stores10 questions on a scale from 0 to 10; (2) Follow-up survey for HUD's Online Training for Realtors- 6 questions on a scale from 0 to 10; (3) Pre- and posttest of training of home buyers- 5 questions; and (4) HUD Curriculum for Inspectors, Contractors, DIY Workers-8 questions. 
Table 1. Summary of outreach and training provided by Community Lead Awareness Partnership (CLAP) for Healthy Kids.

\begin{tabular}{|c|c|c|c|}
\hline Activity & $\begin{array}{l}\text { Data Collection } \\
\text { Procedures }\end{array}$ & Venue for Events & Training Materials \\
\hline $\begin{array}{l}\text { Provide health education } \\
\text { materials, educational } \\
\text { training, and presentations to } \\
\text { community-based } \\
\text { organizations, child-care } \\
\text { centers, and faith-based } \\
\text { organizations }\end{array}$ & $\begin{array}{l}\text { 1. Information, } \\
\text { Education, } \\
\text { Communication } \\
\text { materials given out } \\
\text { 2. Sign-in sheets } \\
\text { 3. Videos, pictogram, } \\
\text { color charts }\end{array}$ & $\begin{array}{l}\text { Churches, Childcare } \\
\text { centers, Elementary } \\
\text { schools }\end{array}$ & $\begin{array}{c}\text { Sesame Street Lead Away Video [18] } \\
\text { (Age of children 3-5). } \\
\text { A Teacher's Guide to How Mother Bear } \\
\text { Taught the Children about Lead } \\
\text { Source: University of Connecticut. } \\
\text { Cooperative Extension System. [19] }\end{array}$ \\
\hline $\begin{array}{c}\text { Host hands-on training on } \\
\text { lead poisoning prevention at } \\
\text { local home-builder retail } \\
\text { stores }\end{array}$ & Exit survey & $\begin{array}{l}\text { Lowe's } \\
\text { Home Depot } \\
\text { Marvin's } \\
\text { Sherwin Williams }\end{array}$ & $\begin{array}{l}\text { Hands-on training and educational } \\
\text { materials }\end{array}$ \\
\hline $\begin{array}{l}\text { Provide lead prevention } \\
\text { training for realtors }\end{array}$ & Follow-up survey & $\begin{array}{c}\text { Housing Alternatives of } \\
\text { Hattiesburg; } \\
\text { Neighborhood } \\
\text { Associations }\end{array}$ & $\begin{array}{l}\text { HUD's Lead-Based Paint Visual } \\
\text { Assessment Training [17] }\end{array}$ \\
\hline $\begin{array}{c}\text { Provide intensive } 8 \mathrm{~h} \text { training } \\
\text { on lead safe work practices to } \\
\text { inspectors, contractors, and } \\
\text { DIY workers }\end{array}$ & Follow-up survey & $\begin{array}{l}\text { City of Hattiesburg } \\
\text { Mayor's Office }\end{array}$ & $\begin{array}{c}\text { PowerPoint presentation; } \\
\text { HUD's Lead-Based Paint Visual } \\
\text { Assessment Training [17] }\end{array}$ \\
\hline $\begin{array}{l}\text { Provide education on lead } \\
\text { poisoning prevention through } \\
\text { home-buyer education classes }\end{array}$ & Pre/Post test & $\begin{array}{c}\text { Housing Alternatives of } \\
\text { Hattiesburg; } \\
\text { Neighborhood } \\
\text { Associations }\end{array}$ & PowerPoint presentation \\
\hline $\begin{array}{l}\text { Provide training on lead-safe } \\
\text { work practices to rental } \\
\text { property owners }\end{array}$ & Follow-up survey & Churches & PowerPoint presentation \\
\hline
\end{tabular}

\section{Results}

The CLAP for Healthy Kids project staff distributed educational materials and presented lectures on lead prevention at several venues and making over 50 public appearances. These events included health fairs, neighborhood meetings, community events, and events at local parks and schools. The total number of participants in this study were 1588 including those who participated in health fairs $(n=467)$, community events $(n=469)$, and Kindergarten classes $(n=241)$, hands-on training at homebuilding retail stores $(n=25)$, HUD's online training $(n=295)$, and training workshops for home-buyers and rental home owners $(n=91)$ (Table 2$)$.

\section{Impact of Hands-On Training, HUD Online Training, and Workshops}

Hands-on training was offered at homebuilding retail stores such as Lowe's, Home Depot, Marvin's, and Sherwin Williams. Of 25 participants, 23 (92\%) reported the hands-on training was very useful or useful on a scale from 1 to 10. HUD's online Lead-Based Paint Visual Assessment Training was given to 220 realtors, and 75 inspectors, contractors, and DIY workers. Training workshops were attended by 91 home-buyers and rental home owners at the Neighborhood Association Meetings.

At posttest, $59.4 \%, 67.9 \%, 65.1 \%$ of the realtors $(n=220)$ identified soil, car batteries and paint as sources of lead in the environment, respectively. Nearly $70 \%$ identified lead as a poison in the environment while $77.5 \%$ and $47.2 \%$ of those surveyed demonstrated two different behaviors which will help prevent lead poisoning. A total of $62.3 \%, 48.1 \%$, and $58.5 \%$, at posttest, identified three complications-behavioral, physical, and psychological, respectively. The mean posttest score was significantly higher than the pretest scores ( $7.47 \pm 2.07$ vs. $6.60 \pm 1.68, p=0.04$, respectively). 
All the participants on HUD online training $(n=75)$ who participated at a 2-month follow-up survey reported that they actually implemented what they had learned during the training on HUD curriculum on lead. The outcome measurements of home-buyer workshops were not significantly different from those of the online training.

Table 2. Impact of the major training activities provided by CLAP for Healthy Kids.

\begin{tabular}{|c|c|c|c|}
\hline Mode of Training & Participants & Assessment & Outcome Measures \\
\hline Health fairs & 467 & - & $\begin{array}{l}\text { Distributed } 1000 \text { educational materials (leaflets } \\
\text { and brochures) }\end{array}$ \\
\hline Community events & 469 & - & $\begin{array}{l}\text { Appeared in } 25 \text { health events. The City Mayor } \\
\text { proclaimed the CLAP for Healthy Kids activities } \\
\text { for lead prevention. }\end{array}$ \\
\hline Kindergarten classes & 241 & - & Students offered a certificate of completion \\
\hline $\begin{array}{l}\text { Hands-on training at } \\
\text { home-building retail stores }\end{array}$ & 25 & Exit survey & $\begin{array}{c}23 \text { out of } 25(92 \%) \text { reported the training was } \\
\text { useful or very useful }\end{array}$ \\
\hline \multirow[t]{4}{*}{$\begin{array}{l}\text { HUD's online Lead-Based } \\
\text { Paint Visual Assessment } \\
\text { Training }\end{array}$} & $\begin{array}{l}220 \text { realtors; } 75 \\
\text { inspectors, contractors, } \\
\text { and DIY workers }\end{array}$ & Follow-up survey & $\begin{array}{c}59.4 \%, 67.9 \%, 65.1 \% \text { of the realtors identified soil, } \\
\text { car batteries, and paint as sources of lead in the } \\
\text { environment, respectively }\end{array}$ \\
\hline & & & $\begin{array}{l}\text { A total of } 62.3 \%, 48.1 \% \text {, and } 58.5 \% \text {, at posttest, } \\
\text { identified three complications-mental, physical, } \\
\text { and psychological, respectively }\end{array}$ \\
\hline & & Pre- and Post-test & $\begin{array}{c}\text { The mean posttest score was significantly higher } \\
\text { than the pretest scores }(7.47 \pm 2.07 \text { vs. } \\
6.60 \pm 1.68, p=0.04 \text {, respectively). }\end{array}$ \\
\hline & & & $\begin{array}{l}\text { All the participants at a } 2 \text {-month follow-up } \\
\text { reported that they actually implemented what } \\
\text { they had learned during the training on HUD } \\
\text { curriculum on lead }\end{array}$ \\
\hline $\begin{array}{l}\text { Training workshops for home } \\
\text { buyers and retail home } \\
\text { owners }\end{array}$ & 91 & Exit survey & $\begin{array}{l}\text { 90\% mentioned the training was useful or very } \\
\text { useful. }\end{array}$ \\
\hline
\end{tabular}

\section{Discussion}

Through the CLAP for Healthy Kids project on lead prevention in Mississippi, a total of 1588 participants took the services. The project offered a number of outreach activities among a wide range of people through health fairs and community events, kindergarten school-based training, training in faith-based organizations and churches, HUD's online free Lead-Based Paint Visual Assessment Training [17], hands-on training, workshops, and lectures. The impact of outreach programs and trainings were successful in improving knowledge of the community people on lead poisoning prevention.

For certain programs such as tenant-based Section 8 rental assistance, the HUD Regulation on Lead-Based Paint Hazards in Federally Owned Housing and Housing Receiving Federal Assistance requires: (1) Visual assessment of housing units for deteriorated paint; (2) The stabilization and repair of all deteriorated paint; and (3) The visual assessor must be trained to perform a visual assessment [20]. Environmental Protection Agency (EPA)'s Renovation, Repair, and Painting (RRP) Rule requires that firms performing renovation, repair, and painting projects use certified renovators who are trained by EPA-approved training providers and follow lead-safe work practices [21]. The training programs of this project were, therefore, in alignment with the EPA/HUDS's objective of encouraging sustainable infrastructure development programs for the prevention of childhood lead poisoning.

Among the programs offered by the project, the number of participants at homebuilding retail stores were not satisfactory. This is a lesson learned that the training 
programs offered through retail stores such as Lowe's and Home Depot may not be suitable because of people's busy schedules and limited time in spending for hands-on training during shopping. One of the most successful of all programs was the EPA/HUD's online free Lead-Based Paint Visual Assessment Training [17]. The reason of success of this program was probably because people had flexibility of scheduling their time for the online training. It is noteworthy that the outcome measurements of home-buyer face-to-face workshops were not significantly different from those of the online training.

One of the strengths of this study was the community engagement from the beginning of the study in the planning, goal setting, project activities, and project evaluation. The project activities were boost up by the proclamation of the Honorable Mayor of The City of Hattiesburg. CBPR and engagement of the community people have been emphasized in many studies for the success of a community-based program [22]. The project also helped in the sustainability of the lead prevention program in the City by providing training of the home inspectors, DIY workers, realtors, home buyers, and the general people.

Similar success stories of educational programs were reported from another communityparticipatory research in Philadelphia involving 1200 children and 900 adults [23]. In the later study, community-developed strategies were created for this project with resident leaders from the community and grassroots agencies serving the community. The grassroots agencies included the Philadelphia Housing Authority Tenant Councils for Norris Homes and Apartments and Fairhill Apartments; the Village of the Arts and Humanities, an organization devoted to introducing the arts and humanities to all socioeconomic groups; the Philadelphia Parent Child Center; the Neighborhood Action Bureau, an economic development corporation; and the Salvation Army.

Another community-based Tribal Efforts Against Lead (TEAL) Project used a lay health advisor model to build capacity in a Native American community to reduce lead exposure in a mining area in northeastern Oklahoma [24]. In the TEAL project, approximately 40 tribal members were recruited from area tribes and trained on lead poisoning and its prevention. For a 2-year period, they educated members of their social networks and worked to implement change in their community to reduce exposure to lead.

One of the limitations of the present study was that it focused on health education only. Although several studies have shown successes in improving education of the people, education alone has a limited effectiveness in alleviating the burden of lead poisoning, especially if it is not combined with resources to actually correct lead-based paint hazards in housing or take remedial measures for other sources of lead poisoning. Studies that evaluated the effectiveness of parents' education alone have failed to show significant reductions in childhood BLLs [25]. Studies are needed to focus on reducing the sources of childhood lead exposures rather than identifying children who have already been unduly exposed or attempting to ameliorate the toxic effects of lead exposure.

\section{Conclusions}

This CBPR was successful in improving people's knowledge in identifying sources of lead, complications, and prevention of lead. The involvement of kindergarten students in learning about lead and its prevention using Sesame Street Lead Away videos was exemplary, and easy-to-adopt in other programs. A comprehensive educational strategy addressing multiple groups of people could be the key to success of the project. However, studies are needed to show the effectiveness of health education in improving people's health behavior. More innovative methods of interventions are needed addressing the needs of high-risk populations and local communities to address their specific health needs for alleviating the risk of lead poisoning in the community.

Author Contributions: Conceptualization, A.K.M.; Data Extraction, A.K.M. and C.A.-L.; Validation, A.K.M.; Original Draft Preparation, A.K.M.; Review \& Editing, A.K.M. and C.A.-L. All authors have read and agreed to the published version of the manuscript. 
Funding: This research was funded by the National community-based lead outreach and training grant, Environmental Protection Agency, Award No. EPA-OPPT-08-003.

Institutional Review Board Statement: The project was approved by the IRB of The University of Southern Mississippi, Hattiesburg, Mississippi.

Informed Consent Statement: The study was conducted according to the guidelines of the Declaration of Helsinki. Informed consent was obtained from all subjects involved in the study.

Data Availability Statement: The data presented in this study are available on request from the corresponding author.

Acknowledgments: The authors appreciate Joel Downey, a Home Specialist and a certified home owner instructor for Housing Alternatives in Hattiesburg, Inc. (HAH) for his contribution in identifying community partners, and in providing support in outreach activities of the project. The authors wanted to express gratitude to Fazlay Faruque, at the University of Mississippi Medical Center, Jackson, Mississippi for GIS mapping of counties of Mississippi for children with lead poisoning.

Conflicts of Interest: The authors declare no conflict of interest.

\section{References}

1. World Health Organization. Preventing Disease through Healthy Environments; WHO: Geneva, Switzerland, 2006.

2. United States Environmental Protection Agency. EPA Recognizes Lead Poisoning Prevention Week 2020. Available online: https:/ / www.epa.gov/newsreleases/epa-recognizes-lead-poisoning-prevention-week-2020 (accessed on 13 December 2020).

3. Centers for Disease Control and Prevention. Preventing Lead Poisoning in Young Children; CDC: Atlanta, GA, USA, 2005. Available online: www.cdc.gov/nceh/lead/publications/PrevLeadPoisoning.pdf (accessed on 12 December 2020).

4. U.S. Department of Housing and Urban Development. American Healthy Homes Survey—Lead and Arsenic Findings. Available online: https: / / www.hud.gov / sites / documents / AHHS_REPORT.PDF (accessed on 22 December 2020).

5. Centers for Disease Control and Prevention. Childhood Lead Poisoning Prevention in Newly Arrived Refugee Children: Tool Kit. Available online: https://www.cdc.gov/nceh/lead/publications/refugeetoolkit/refugee-tool-kit.htm (accessed on 2 December 2020).

6. Agency for Toxic Substances \& Disease Registry. Toxicological Profile for Lead. Available online: https://www.atsdr.cdc.gov/ ToxProfiles $/$ tp.asp?id=96\&tid=22 (accessed on 22 December 2020).

7. Greig, J.; Thurtle, N.; Cooney, L.; Ariti, C.; Ahmed, A.O.; Ashagre, T.; Meredith, C. Association of blood lead level with neurological features in 972 children affected by an acute severe lead poisoning outbreak in Zamfara State, Northern Nigeria. PLoS ONE 2014, 9, e93716. [CrossRef] [PubMed]

8. Kuang, W.; Chen, Z.; Shi, K.; Sun, H.; Li, H.; Huang, L.; Bi, J. Adverse health effects of lead exposure on physical growth, erythrocyte parameters and school performances for school-aged children in eastern China. Environ. Int. 2020, 145, 106130. [CrossRef] [PubMed]

9. Geier, D.A.; Kern, J.K.; Geier, M.R. Blood lead levels and learning disabilities: A cross-sectional study of the 2003-2004 National Health and Nutrition Examination Survey (NHANES). Int. J. Environ. Res. Public Health 2017, 14, 1202. [CrossRef]

10. Hauptman, M.; Stierman, B.; Woolfe, A.D. Children with autism spectrum disorder and lead poisoning: Diagnostic challenges and management complexities. Clin. Pediatrics 2019, 58, 605-612. [CrossRef]

11. Zimmerman, E.; Borkowski, C.; Clark, S.; Brown, P. Educating speech-language pathologists working in early intervention on environmental health. BMC Med. Educ. 2018, 18, 155. [CrossRef] [PubMed]

12. Santa Maria, M.P.; Hill, B.D.; Kline, J. Lead (Pb) neurotoxicology and cognition. Appl. Neuropsychol. Child 2019, 8, 272-293. [CrossRef] [PubMed]

13. Mitra, A.K.; Haque, A.; Islam, M.; Bashar, S. Lead poisoning: An alarming public health problem in Bangladesh. Int. J. Environ. Res. Public Health 2009, 6, 84-95. [CrossRef] [PubMed]

14. U.S. Department of Health and Human Services. Office of Disease Prevention and Health Promotion. Healthy People 2020. Environmental Health. Available online: https:/ /www.healthypeople.gov/2020/topics-objectives/topic/environmental-health/ objectives (accessed on 13 December 2020).

15. U.S. Department of Health and Human Services. Office of Disease Prevention and Health Promotion. Healthy People 2030. Available online: https:/ / health.gov/healthypeople (accessed on 13 December 2020).

16. American Academy of Pediatrics; Committee on Environmental Health. Screening for elevated blood lead levels. Pediatrics 1998, 101, 1072-1078. [CrossRef] [PubMed]

17. U.S. Department of Housing and Urban Development (HUD). Lead Based Paint Visual Assessment Training Course. Available online: https:/ / apps.hud.gov/offices/lead/training/visualassessment/h00101.htm (accessed on 10 December 2020).

18. Prudential Foundation. Sesame Street Lead Away Video. Available online: https://video.search.yahoo.com/yhs/search?fr= yhs-avast-securebrowser\&hsimp=yhs-securebrowser\&hspart=avast\&p=Sesame+Street + Lead + Away + Video\#id=1\&vid=fa961 93dfd221faac764df6ffb47eda2\&action=click (accessed on 13 December 2020). 
19. University of Connecticut; Cooperative Extension System; College of Agriculture and Natural Resources. A Teacher's Guide to How Mother Bear Taught the Children about Lead. Available online: https://kids.niehs.nih.gov/assets/docs/teachers_guide_50 8.pdf\#: \{ \{\}:text=How\%20Mother\%20Bear\%20Taught\%20the\%20Children\%20about\%20Lead\%3A,individually\%2C\%20in\%20 small\%20groups\%2C\%20or\%20as\%20a\%20class (accessed on 13 December 2020).

20. U.S. Department of Housing and Urban Development (HUD). What Does the Regulation Require? Available online: https: / / archive.epa.gov/epa/lead/lead-outreach-partnerships-and-grants.html (accessed on 13 December 2020).

21. Environment Protection Agency. Lead Outreach, Partnerships and Grants. Lead Renovation, Repair and Painting (RRP) Rule. Available online: https:/ / archive.epa.gov/epa/lead/lead-outreach-partnerships-and-grants.html (accessed on 13 December 2020).

22. Lasker, R.D.; Weiss, E.S. Broadening participation in community problem solving: A multidisciplinary model to support collaborative practice and research. J. Urban Health 2003, 80, 14-60. [CrossRef] [PubMed]

23. Rothman, N.L.; Lourie, R.J.; Gaughan, J. Lead awareness: North Philly style grant team. Am. J. Public Health 2002, 92, 739-741. [CrossRef] [PubMed]

24. Kegler, M.C.; Malcoe, L.H.; Lynch, R.; Whitecrow-Ollis, S. A community-based intervention to reduce lead exposure among Native American children. Environ. Epidem. Toxicol. 2000, 2, 121-132.

25. American Academy of Pediatrics. Prevention of childhood lead toxicity. Pediatrics 2016, 138, e20161493. [CrossRef] [PubMed] 